University of Louisville

ThinkIR: The University of Louisville's Institutional Repository

Faculty Scholarship

Fall 2010

From Pound to Olson: The Avant-Garde Poet as Pedagogue

Alan Golding

University of Louisville

Follow this and additional works at: https://ir.library.louisville.edu/faculty

Part of the English Language and Literature Commons, and the Poetry Commons

Original Publication Information

Golding, Alan. "From Pound to Olson: The Avant-Garde Poet as Pedagogue." 2010. Journal of Modern Literature 34(1): 86-106.

This Article is brought to you for free and open access by ThinkIR: The University of Louisville's Institutional Repository. It has been accepted for inclusion in Faculty Scholarship by an authorized administrator of ThinkIR: The University of Louisville's Institutional Repository. For more information, please contact thinkir@louisville.edu. 


\section{From Pound to Olson: The Avant-Garde Poet as Pedagogue}

\section{Alan Golding}

University of Louisville

Ezra Pound's sense of himself as poet-pedagogue - including his insistent desire to reform American higher education - is inseparable from his literary avant-gardism and his commitment to the principle of "discovery" or "newness." This connection between experimental poetics and pedagogy forms a central part both of Pound's significance as a writer and of his influence on a later avant-gardist and didact like Charles Olson, and anticipates the complexities of the subsequent relationship between American poetic avant-gardes and the academy. Olson was both a teacher at and rector of Black Mountain College, and in an unlikely conjunction, the forms of his institutional life enter the forms of his avant-garde poetics in major poems like "The Praises." At the same time, his work embodies a continuing conflict within avant-garde poetics that is central equally to him and Pound: the conflict between the (public) didactic impulse and the (private) impulse toward preservation of coterie.

Keywords: Ezra Pound / Charles Olson / pedagogy / avant-garde / poetics

He could not keep himself from teaching. In one way or another he was always teaching.

- James Laughlin,

"Pound’s Pedagogy" 34.

\footnotetext{
$\mathbf{E}$
} zra Pound's persistent writing of textbooks and guides, his generation of reading lists and of anthologies both disguised (ABC of Reading) and fullfledged (Confucius to Cummings) and his career-long railing against the academy all reflect his sense of himself as poet-pedagogue. This much is hardly news, and numerous aspects of Pound's relationship to teaching and its institutions are explored in work as theoretically divergent otherwise as James Laughlin's informal essay “Pound's Pedagogy," Kathryne Lindberg's Reading Pound Reading and Gail McDonald's Learning To Be Modern: Pound, Eliot, and the American University, a book written on the premise that "teaching is a subtext of modernist poetry, and the university an important presence” (139). I have addressed the issue briefly myself, discussing Pound as a canonizing poet-critic, in my own From Outlaw 
to Classic: Canons in American Poetry. Here I want to take a different approach to Pound the teacher, however, in arguing that his pedagogic stance-including his insistent desire to reform American higher education - is inseparable from his literary avant-gardism and his commitment to the principle of "discovery" or "newness." This connection between experimental poetics and pedagogy forms a central part both of Pound's significance as a writer and of his influence on a later avant-gardist and didact like Charles Olson. ${ }^{1}$ When Olson responds to Pound in his poetry, he does so partly as student to teacher (in "I, Mencius, Pupil of the Master"), and also in terms established by Pound's own avant-gardist pedagogy (in "The Praises"). Avant-gardes have always been didactic, in their production of manifestoes, their strong element of social critique, and their claims on the art of the future..$^{2}$ Pound stands at the head of a line of twentieth-century American avant-garde didacts, in a way that invites us to consider how the Poundian principle "make it new" connects to the pedagogical thrust of his own and much other experimental writing, and how Pound lays the groundwork for a speaker in a key text of the Language movement, Lyn Hejinian's My Life, to ask the rhetorical question "Isn't the avant-garde always pedagogical [?]" (92). ${ }^{3}$

If Pound's pervasive didacticism, his pedagogical bent, is a critical commonplace, his persistent address to pedagogical institutions would seem to be unusual, even paradoxical, for any self-proclaimed avant-gardist. Except for Eliot, whose lifelong engagement with the academy and in commentary on higher education McDonald has thoroughly demonstrated, most of Pound's immediate contemporaries and associates had little to say to or about universities, beyond the occasional barb. But Pound addresses teaching institutions in a way that will become increasingly typical of experimental American poets. Making the academy both object of critique and an implied addressee renders Pound unusual among early twentieth-century avant-gardists. At the same time, it anticipates the complexities of the subsequent relationship between American avant-gardes and the academy that we see reflected in such institutions as the Olson-directed Black Mountain College of the 1950s and the SUNY Buffalo Poetics Program, now perhaps the nation's most visible state-funded academic site for the study and production of alternative poetries.

In The Trouble with Genius, Bob Perelman lays out effectively Pound's simultaneous desire to teach and his suspicion of teaching institutions ("beaneries," in his notorious term), his contradictory impulses both to exclude and to instruct from his position as self-constructed "genius." Pound divides readers between the few initiates into the sacred realm of poetry who see by the light of immediate, self-evident truth and the many laboring in dullness, who need poetry's instruction and yet, because of Pound's "denial that sacred knowledge can circulate" (Perelman, Trouble 58), are refused it or seen as immune to it. Thus conflicts between the simultaneous communicability and incommunicability of knowledge, the teachability and unteachability of reader-students, are constitutive of Pound's pedagogical poetics. I use the term "reader-students" because readers are almost always students also to Pound ("the reader, or class" [Guide 318]); as Gail 
McDonald puts it, "Pound had no relationship that was not pedagogic and wrote no poetry or prose that did not consciously instruct" (61). On the one hand, then, we have the widely cited formulation from Guide to Kulchur:

Prose is NOT education but the outer courts of the same. Beyond its doors are the mysteries. Eleusis. Things not to be spoken of save in secret. The mysteries selfdefended, the mysteries that can not be revealed. Fools can only profane them. The dull can neither penetrate the secretum nor divulge it to others. (144-45)

The envoi to Pound's translation of Cavalcanti's "Donna mi priegha" in Canto 36 projects a similarly elite sense of audience:

For so art thou ornate that thy reasons

Shall be praised from thy understanders,

With others hast thou no will to make company. (Cantos 179)

On the other hand, by the time that Pound said of the "mysteries" in a 1939 letter that "no guide book to them has been or will be written" (Letters 327), he had already written a number of such guides himself and would write more. Pound allows for what he calls the "intelligent lay reader" (Literary Essays 39) as often as he dismisses that reader. In the late anthology, Confucius to Cummings, he writes "any reader who has been able to get into a junior college will be able to put our mosaic together to her, or to his, satisfaction" (x).

Historically, we can locate Poundian pedagogy partly in relation to the Great Books movement within American higher education in the first half of the twentieth century. This movement is associated with Charles Eliot's set of Harvard Classics (1909), which popularized the metaphor of the five-foot bookshelf; with John Erskine's "General Honors" course at Columbia, inaugurated in 1921 (Erskine was one of the first to use the term "Great Books"); and with the highly visible 1931 University of Chicago course modeled on Erskine's and taught by his student Mortimer Adler and Robert Maynard Hutchins. Adler in particular became well-known for his series of "how to" intellectual primers, including How to Read a Book (1940). Pound's persistent pedagogical manifestoes and reading lists, his obsession with the widespread circulation of a highly selective canon ("The thought of what America would be like / If the Classics had a wide circulation / Troubles my sleep” [Personae 194]), resemble this drive within mainstream education and fit within contemporary debates over educational methods and philosophy more than he might like to admit. ${ }^{4}$ The idea of "the Classics," however, marks a typically Poundian site of pedagogic tension. He can write of "faddists and university infants card[ing] out again the overcombed wool of a limited set of 'classics" (Guide 217), and his own massive learning far outstrips such limits. The educational system overlooks or obstructs the circulation of vast amounts of worthwhile material, as Pound learned at the University of Pennsylvania in 1906 when he was prevented from "doing a thesis on some reading matter OUTSIDE the list of classic authors included in the curriculum" (215-16). But Pound's railing against the curricular recirculation 
of a "limited set of "classics" rather transparently rests on resentment that it is not his "set of classics." In a form of authoritarianism inseparable from his enthusiasm, the absence of one of Pound's canonical figures from the study of any given discipline is enough to damn the enterprise from the start. Thus he writes to Lawrence Scott, a student at the University of Michigan with whom he had entered into an openly pedagogical correspondence, that it is "ASSinine, beastly imbecility to think of study of ANY bdy/religion without Frobenius" (qtd. in Marshall 143). He follows up with the imperative to, "if yr/prof/any good, keep HAMMERING on idiocy of Philosophy courses without Kung" (qtd. in Marshall 144) - a way of thinking that parallels his prophetically New Historicist assertion that "a history of American literature that omits the letters of the founders and memoirs or diaries of J. Q. Adams and Martin van Buren is merely nonsense" (Selected Prose 118). While from one point of view there may be some basis for Pound's complaint about "basing curricula on material available 300 years ago, and neglecting all new knowledge," the context of the Great Books debate renders rather flimsy his claim that "our universities have given NO thought whatever to adjusting curricula so as to include and/or prefer the best available "classics"' (Guide 313-14).

Michael Coyle argues that "the work of popularization occupied a sustained and central position in Pound's activity as a writer" (125) from The Spirit of Romance on and usefully places Pound's primers of the 1930s in a long line of popularizing texts. Models for Pound's $A B C$ of Economics, for instance, go as far back as 1815, with multiple texts specifically in the "ABC of" or "Alphabet of" format appearing between 1877 and 1937, including his friend A. R. Orage's 1917 Alphabet of Economics (Coyle 128-31). While Pound's impulse toward popularization conflicts with his snobbery toward popular audiences, the conflict derives from his attempt "to synthesize two rather different understandings of the idea of culture," a populist definition of culture as "the totality of a people's life" and a mandarin definition of it as "the rarefied and privileged" Arnoldian "best" (143). From a different angle, the conflict can be seen as methodological, the kind of contradiction that Michael Davidson addresses in discussing Pound's critique of philology: as Davidson puts it, that critique "proceeds by means of the very methods it stresses - as though by quoting chapter and verse he may assign value to Theocritus and Yeats while indicting those professional, academic structures that remove them from art" (Ghostlier Demarcations 99). ${ }^{6}$

Part of what is striking in Pound's thinking about pedagogy is the sheer longevity of his obsessive railing against educational institutions, from the early examples of his 1906 essay "Raphaelite Latin" and The Spirit of Romance (1910) to the "dung flow" and "kikery" of "the american beaneries" (explicitly including Hutchins) in Canto 91 (Cantos 628) — though the extent to which such formulations as "kikery" count as "thinking" is debatable. After all, one of his final publications is the co-edited textbook anthology Confucius to Cummings (finished in 1958, apparently, though published in 1964, and unusually lacking in vituperation). If the beaneries were so worthy of contempt, why did Pound not simply turn 
his back on them after a while and stop talking about, or addressing, them? How do we explain Pound's ambivalent relationship and ongoing address to pedagogical institutions? To answer this question, we have to assume that Pound saw the academy as both audience and potential outlet or conduit for the cultural values he espoused (though his own work was not widely taught for years), a site worth redeeming. His ambition is oddly utopian, as if Pound cannot give up on some faith that universities can indeed play a crucial role in the transformation of culture - a very American view, perhaps, of the potential place of higher education in a democracy. Universities, the beaneries, are miasmas of willed ignorance and financial corruption, but rather than simply turning his back on them, as many writers would and did, he continues to address them, to exhort change. At the same time, however, the democratic thrust of American higher education works against the 500-600 "men" necessary for a civilization: "University not here for the unusual man,' Prof. S. re Carl Sandburg" (Guide 345). Neither is the institution flexible enough to adapt itself to the circulation of relevant contemporary knowledge. Pound returns consistently to the example of the student who would not study economics at Cambridge because of the university's failure to adjust its teaching to the needs of the present: the professor, apparently, "'admitted that it had nothing to do with real life but said that the course could not be changed. I therefore did not take the course.' This from a Cambridge (England) student who had thought of studying economics in that beanery" (56).

Pound's pedagogical rhetoric typically mixes the languages of mysticism and professionalism, as in his account of the trainee or neophyte who emerges "licensed, an initiate" (Selected Prose 35). Those followers can be seen to parallel the particular readers whom Pound often finds redeemable while damning readers in general. According to the model proposed in the famous teaching anecdote of Louis Agassiz and the fish, the inscrutable master pedagogue moves students toward enlightenment one by baffled one, but actually education proceeds by moments of unmediated revelation from Pound's earliest essays on: "Janus of Axel had forestalled and superseded the science of pedagogy with 'I instruct not; I awake" ("Raphaelite Latin" 8). The imperative mode of Pound's most widely reprinted essay, "A Retrospect," suggests his sense that the reader, as I've said, is nearly always to be seen as a student or, in the terms of the essay, a "candidate" or "neophyte" to be force-fed: "The present chaos will endure until the Art of poetry has been preached down the amateur gullet" (Literary Essays 10). But again, if one can be a neophyte, one can become an initiate. On the one hand, Pound insists on specialized knowledge; on the other, he validates and persistently addresses a lay reader. In Guide to Kulchur, Pound criticizes Greek philosophy for what he considers its coterie, undemocratic practices, for losing touch with the polis: "You may with almost complete justice assert that greek philosophic thought is utterly irresponsible. It is at no point impregnated with a feeling for the whole people. It was mainly highbrow discussion of ideas among small groups of consciously superior persons, Curzons, etc., who thought themselves above the rest of society" (29-30). 
To examine these competing pulls in the relationship between Pound's avantgarde sense of audience and his pedagogy, and to look more closely at his method, I will turn to three of his most obviously pedagogical texts: "How to Read" (1929), the extension of that essay into $A B C$ of Reading (1934), and, briefly, "The Teacher's Mission" (1934). Pound dedicates "How to Read" (1929) to "starters of ideal universities" (Literary Essays 22), one of which John Rice believed he was starting in Black Mountain, North Carolina only four years later. ${ }^{7}$ In "How to Read," Pound would replace university instruction with his own; the polemically titled essay begins with a critique of "literary instruction in our "institutions of learning"" (15). "How to Read" makes clear the extent to which formal "discovery" - Pound's term - makes up the center of his pedagogy. "Inventors" and "masters [of invention]" are the highest level of poet; the ideal literary pedagogy would "proceed by a study of discoveries" that, like much Poundian knowledge, are taken as self-evident ("known discoveries, clearly marked"). This pedagogy is enabled by the ideal anthology, one "in which each poem was chosen ... because it contained an invention" (17-19). Despite their failures, teachers are one of Pound's primary audiences, and he offers a characteristic reading list, complete with metaphors of sanitizing and health, intended as "the minimum basis for a sound and liberal education in letters," a minimum "curriculum for instructors [and] for obstreperous students who wish to annoy dull instructors" (38). The didactic impulse here is to reform teaching, the assumption being that university teachers already represented one primary set of potential mediators for poetry. What needs reforming specifically is pedagogical method, that combination of philology and critical history into which the New Criticism so effectively intervened in the years that Pound was producing his own textbooks, and that he consigned to Hell in Canto 14: "pandars to authority, / pets-de-loup, sitting on piles of stone books, / obscuring the texts with philology, / hiding them under their persons" and acting like corporate "monopolists, obstructors of knowledge, / obstructors of distribution" (Cantos 63).

Crucial to Pound's educational polemics is the connection that he presumes between effective teaching and a limited canon, the highest canonical status being reserved only for the aforementioned "inventions" and "discoveries." The curriculum of "How to Read" is designed to cultivate critical judgment, evaluation, the absence of which is in Pound's view one flaw in contemporary teaching. As a result, "if a man knows the facts" about a Poundian canonical text, "he can evaluate almost any unfamiliar book at first sight" (23-24). When Cary Nelson, in his influential Repression and Recovery (39-40, 52-54), proposes separating canon formation and literary history as competing activities, he responds partly to an academic conflation of these discourses that derives from the high modernism of a Pound, who treats literary history and evaluation as one. This conflation of literary history and canon formation is one of the central moves of $A B C$ of Reading (1934), published in the same year that the young American Studies scholar Charles Olson was reconstructing Herman Melville's library between earning an MA at Wesleyan and beginning an instructorship at Clark. 
Building on "How to Read," Pound sees $A B C$ of Reading as offering steps toward a canon: "gradus ad Parnassum" (9). Evaluation or critical judgment for Pound remains a means to enlivening and streamlining the academic canon, producing a "drastic separation of the best" from the mass of material "that has overweighed all curricula" (13) in the previous fifty years of the Luddite bureaucracy that is American higher education. He remains convinced that both teaching and learning rest on the idea of a limited canon: "a man can learn more about poetry by really knowing and examining a few of the best poems than by meandering about among a great many" (43). Those "best" poems either emerge self-evidently from exercise of the Poundian ideogrammic method, which I'll discuss in a moment, or are proposed by Pound himself. He seems to invite students to become their own canonizers: "Pick out the dozen best old ballads. Pick out the twenty-five best lyrics written between 1500 and 1700 from any of the available anthologies" (79). Such exercises presume knowledge more than they teach, however, and Pound's apparent concessions to student individuality - "the questions in this exercise do not demand the same answer from any two pupils" (80) - are disingenuous because those questions are so frequently rhetorical. An apparent "assignment" like "Try to find a poem of Byron or Poe without seven serious defects" (79) actually asks for nothing more than assent to Pound's judgment of the poets concerned.

Formally, Pound's pedagogic method is one with his poetic method: parataxis. He narrates an experiment in musical taste structured around juxtaposition, in which, after two musical evenings six weeks apart featuring one Debussy and one Ravel piece among a range of other work, "everyone present at the two concerts now knows a great deal more about the relations, the relative weight etc. of Debussy and Ravel" ( $A B C 24$ ) than they would have done from reading music criticism. This teaching experiment extends what Pound had called as early as 1911 his "New Method in Scholarship," "the method of Luminous Detail" (Selected Prose 21). In 1934 he calls this method, with characteristic emphasis, "THE IDEOGRAMMIC METHOD OR THE METHOD OF SCIENCE" ( $A B C$ 26): comparison and evaluation by juxtaposition. In other words, when extended to criticism or pedagogy, parataxis, the method of Pound's mature poetry, becomes a method of evaluation, a means toward the emergence of selfevident quality or superiority:

Hang a painting by Carlo Dolci beside a Cosimo Tura. You cannot prevent Mr. Buggins from preferring the former, but you can very seriously impede his setting up a false tradition of teaching on the assumption that Tura has never existed, or that the qualities of the Tura are non-existent or outside the scope of the possible. (ABC 26)

Here, parataxis yields a level of information, or is a way of imparting information, that in turn opens up a narrow pedagogy. In “The Teacher's Mission," an essay from the same year as $A B C$ of Reading, Pound connects the ideogrammic method with pedagogy even more explicitly: "All teaching of literature should be performed by the presentation and juxtaposition of specimens of writing and 
NOT by discussion of some other discusser's opinion about the general standing of a poet or author" (Literary Essays 60). It is from this point of view that the traditionally conceived anthology, structured as it is, at least theoretically, around juxtaposition of "the best," has potential to be the ideal Poundian teaching tool. For Pound, however, the anthology as a genre consistently fails. Sometimes the scholarship is flawed, constituting an example of "false witness": "a well-known anthology by a widely accepted anthologist contains a mass of simple inaccuracies, statements contrary to simple, ascertainable chronology" (63). ${ }^{8}$ A different form of editorial bad faith is exhibited in the Oxford Book of [English] Verse, which "includes the first five of the strophes [of Donne's "The Ecstasy"] and then truncates the poem with no indication that anything has been omitted" (ABC 140). ${ }^{9}$ Pound observes "the general welter of mediocre performance exhibited in the current anthologies where the best is often obscured" (136), while "traditional miscellanies" are "copied one from another with no critical plan, small honesty, and almost no personal estimate, or re-examination of their matter" (136) - a prophetic critique of anthologies that has subsequently become common. The factors behind this editorial "small honesty" might include the capital investment of publishers in a particular self-replicating canon. According to Pound, when he approached Macmillan in 1916 about a multi-volume anthology "to replace that doddard Palgrave," he was turned down on the basis that the publisher's "whole fortune ... . [was] founded on Palgrave's Golden Treasury" (Literary Essays 18). And he later had yet another proposal, a short anthology-textbook, turned down (22) - the book, apparently, that became $A B C$ of Reading.

Parataxis as a pedagogic method rests on the principle of self-evidence that represents another key component of Poundian teaching. By presentation and juxtaposition, the "relative weights" of the art works in question will magically reveal themselves, presumably on some unspoken but universal scale, becoming their own form of luminous detail. But the valuable works are taken paradoxically both as self-evident and constantly in need of explanation. Indeed, from one point of view, Pound's career as a kind of teacher consists in explaining why everything that he is talking about does not - or should not - need explaining, putting in some perspective Gertrude Stein's famous potshot at him as a "village explainer" (Selected Writings 189). The central irony in Pound's self-construction as teacher is the way in which self-evidence, one of his primary pedagogic principles, contradicts his persistent impulse to explain: "There is probably no use in telling this to people who can't see it without being told" ( $A B C$ 82), but I'll go ahead and tell them anyway.

Pound's paratactic poetics, then, both embodies the tension between democratic inclusion and coterie exclusion in his attitude toward reader-students and yields an ideogrammic method of scholarship and teaching designed to produce a limited canon and highlight aesthetic invention by juxtaposing specimens, a process through which the superior artifact shines forth in the clean bright light of its own self-evident excellence. His poetics also becomes a pedagogy in the way his use of personae functions at certain moments of instruction or institutional 
critique in his oeuvre. In Canto 13, we see Pound-as-Confucius imparting wisdom to a handful of earnest acolytes, of prospective initiates. In "The Jewel Stairs' Grievance," Pound-as-Li-Po provides a lesson on how to read his own emergent modernism. Pound-as-Dante consigns contemporary academics to hell for "obscuring the texts with philology." Pound-as-Sextus-Propertius rescues a cleansed and crystallized canon, "a few pages brought down from the forked hill unsullied," in contrast to the drudges or "annalists [who] will continue to record Roman reputations" (Personae 217). We have Pound-as-Agassiz teaching by the light of self-evident description and juxtaposition of specimens. We have the voice of Henry Adams, Agassiz's near-contemporary at Harvard and disillusioned by his own work there, declaring "Teach? At Harvard? / Teach? It cannot be done" (Cantos 447). ${ }^{10}$ Pound often inhabits other voices to articulate a pedagogy, to critique the academy, and, among other things, to propose a pedagogical model of education as conversation and to open up one key pedagogical question, that of error and authority.

While Pound's own formal teaching career lasted only a few months, he continued to think of himself as an unaffiliated teacher, engaged in educating an audience in how to read and in curing the deficiencies of the "beaneries." “The Jewel Stairs' Grievance” (1915) uses both translation and a persona-a double indirection appropriate for a poem promoting indirectness as an aesthetic value - to embody the relationship between "newness" (that key term of Pound's poetics) and teaching, the teaching of the new:

The jewelled steps are already quite white with dew,

It is so late that the dew soaks my gauze stockings,

And I let down the crystal curtain,

And watch the moon through the clear autumn.

NOTE. - Jewel stairs, therefore a palace. Grievance, therefore there is something to complain of. Gauze stockings, therefore a court lady, not a servant who complains. Clear autumn, therefore he has no excuse on account of weather. Also she has come early, for the dew has not merely whitened the stairs, but has soaked her stockings. The poem is especially prized because she utters no direct reproach. (Personae 142)

(Parenthetically, we might recall the epigraph of Cathay, in which the poem first appeared: "for the most part from the Chinese of Rihaku, from the notes of the late Ernest Fenollosa, and the decipherings of the Professors Mori and Ariga" [Personae 136]. Here academic work can provide the groundwork for poetry. Throughout his career, Pound willingly acknowledges the contributions and expertise of individual scholars; it's the anonymous mass of scholars that he slams.) ${ }^{11}$ The lesson in “The Jewel Stairs' Grievance” involves how to read Pound's emergent modernism, and it occurs in the relationship between poem and note, between "primary" text and the pedagogical commentary on it-between poet and teacher. This note does not provide extra information about the poem's content, explain an allusion or identify a source. It is not the kind of note we recognize 
from today's massive classroom anthologies. Rather, in a striking moment of self-mediation it offers instructions on how to read the parataxis of Pound's modernism, containing the whole method of that modernism within a few short sentences. As emergent modernist readers, we are to infer narrative, social context and emotional tenor from concrete images. Pound's note, in the voice of the teacher, fills in the suppressed logic of the paratactic master text, and concludes with a canonizing judgment: "The poem is especially prized because she utters no direct reproach." What are we to make of that passive verb? The poem is "prized" by Sinologists? Hardly — we know that from their responses. By generations of readers? By Pound himself? (Well, that's a given.) Doesn't "prized" really mean "praiseworthy?" More to the point, Pound wants the aura of authority that the passive verb imparts. He is praising Eliotic "impersonality," emotion communicated via compressed image rather than statement. Not incidentally, this praise also reflects a now-familiar gender dynamic within high modernism: in uttering no direct reproach, "she" remains "free from [the] emotional slither" (Literary Essays 12) with which Pound commonly associated women and women's writing. In multiple ways, then, "The Jewel Stairs' Grievance” is a teaching parable, a lesson in how to read.

In Canto 13, where Confucius makes his first significant appearance in the Poundian poetic canon, he is a teacher with a small group of named followers, an obscure coterie (“we are unknown,' said Kung” [Cantos 58]), who makes authoritative statements intended to shine by the light of their own self-evident truth - a model for the Ezuversity, and later (if only by analogy) for Olson's Black Mountain College, a community constructed in coterie terms, I will argue later, in a poem like Olson's “The Praises." (Kung's coterie perhaps also parallels the minority of particular readers who are redeemable out of the general mass of ignorance in $A B C$ of Reading.) While Canto 13 seems not to be widely discussed as a scene of teaching, it anticipates Walter Baumann's description of Pound's "followers, squatting round their latter-day Confucius in the hospital's park" (13) at St. Elizabeth's, or A. Alvarez's portrait of Pound “'surrounded by his disciples and ... talking politics"” (qtd. in Baumann 13).

Canto 13 is paratactically organized, with the word "and" appearing 36 times, 34 of them at the beginning of lines. It is unusual in Pound's poetry for featuring full predication and for its uninterrupted narrative thrust. The parataxis is key for suggesting Kung's resistance to overt systematic totalizing (though he surely has a system) and a kind of democracy of attention, the indulgence one reserves for the student who insists that Frost's "The Oven Bird" is a poem about Thanksgiving. All Kung's students' responses are equally valid: “'They have all answered correctly, / That is to say, each in his nature" (Cantos 58). Here parataxis is the syntax of equality in difference, emphasizing coordination over subordination, rather than the structural basis for hierarchical judgments that it becomes in Pound's pedagogical prose texts. But if parataxis in this scene of teaching anticipates the method, if not the effect, of these texts, it also recalls the Biblical cadences in which Pound narrates Peter Abelard's ascension to the status of master teacher, a 
narrative repeated or invoked through much of his work. In "America: Chances and Remedies III" that narrative runs thus:

[Abelard] came down to Paris and there found someone, whose name I and nearly everyone else have forgotten, holding the chair of philosophy, and Abelard engaged the gentleman in dispute and very shortly thereafter the gentleman whose name we have forgotten was holding his classes at some place or other down the river, and Abelard was discoursing in Paris.

And in course of time Abelard was called home to attend to the execution of his father's will and estate or something of that sort. And the professor returned to Paris. And later Abelard returned to Paris and the professor departed.

And Abelard took up the ascetic life and went into the wilderness, and five thousand students went after him and camped in the wilderness, enduring all manner of hardships. And all this befell at a time when the universities were a far from negligible factor in the intellectual life of Christendom. $(37)^{12}$

In Pound's exaggerated and wishful allegory of pedagogic authority, Abelard draws students away from the university like an intellectual Pied Piper. If Abelard / Christ's triumph in and departure from the university and his intellectual feeding of the five thousand has narrowed to Kung discoursing with a few neophytes, nevertheless the model of education as pastoral conversation is remarkably similar (if oversimplified). Pound puts the point of the anecdote more succinctly in Guide to Kulchur, returning us to the idea of "apostolic succession": "University LIFE was such and at its apogee when the professor was expected to answer an opponent. Abelard went to Paris and defeated his precursor" (170).

The notorious (and later corrected) printer's error toward the end of Canto 13 that repeats three lines may be "sanctioned by time and the author, or rather first by the author" (Kenner xiv), as Pound responded to Hugh Kenner's inquiry about it, but that sanctioning only compounds, rather than resolves, the complexity of that particular moment in the text: "'A day when the historians left blanks in their writings, / I mean for things they didn't know, / But that time seems to be passing"' (Cantos 60). ${ }^{13}$ This moment concerns ignorance and error, charged issues for Pound's readers in ways that he could not imagine in 1923 when he composed Canto 13, but also important for any consideration of pedagogical authority in the Canto. In one reading, the repetition reinforces the intellectual and moral rectitude of Confucius's attitude toward historical writing and stresses the moment of cultural transition in which that rectitude "seems to be passing." From this point of view, the error's repetition constructs an intensified aura of aphoristic wisdom under which the importance of the repeated content ("this is important enough to say twice") outweighs the claims of textual accuracy (the concerns, we might say, of the philologists whom Pound lambasts so passionately throughout his career). In a more metatextual reading, the repetition, and Pound's sanctioning of it, enshrines error itself as a constitutive feature of the Cantos, apparently in deep tension with Pound's claims to authority. In this reading, it is the fact of the error 
(not what the erroneously repeated statement says) that points up the ethical role of flaws or gaps in historical writing.

For Christine Froula, such embrace of error is inseparable from the Cantos' rhetorical and pedagogical authority, "a concept of authority that includes the collaborative and the contingent" (3). Froula summarizes the process by which we came to "two authoritative editions of The Cantos [the British and the American] which differ from one another in hundreds of lines" (139). Textually "the defects inherent in [the Cantos'] record of struggle" (Pound, Guide 135) manifest as irresolvable errors that paradoxically constitute part of the text's authority even as they subvert any possibility of an authoritative text. As Froula puts it:

The errors which the editors attempted to correct cannot be conceived apart from the authority that informs the poem as a whole, in all its complexities. The errors which Pound wished not to correct must be understood as a part of his 'intentions' for the poem, in relation both to his aims for the poem at the outset and to the final achievement that the words on the page constitute. (151)

Indeed, evidence from an unpublished 23 Feb. 1949 letter to Eliot suggests that Pound saw the incorporation of deliberate textual error as serving the rhetorical purpose of disarming the reader and lending credibility to his didacticism, as if he were aware that his more egregiously confident moments rendered him suspect (especially by 1949). He writes “D. says creees takes three blinkin eee's. I don't care which way it is printed. A little saving ignorance on the part of the bard might allay venom," and again "even the double 11 in balladines can stay as sign of author's iggurunce" (qtd. in Froula 143) — an ignorance that he is constructing as an effect by preserving what he knows to be an error. For Pound, gaps and provisionality are a perfectly acceptable part of the process of renewing education: "a new learning is necessary," and "bilingual texts of the classics cd. be turned out in a few years. At least in the form of drafts, with blanks left for their editor's own lacunae, and no dishonour" (Guide 151).

The instructive gap in Canto 13 may be a gap in writing, but the central pedagogy at work there is oral, that of energetic conversation - exactly the term for the interaction that Pound / Kung uses in the prose version of the narrative that appears in "Imaginary Letters," themselves written in the persona of "Walter Villerant," and one of his recurrent models for the teaching process. Furthermore, within the pedagogic conversation of Canto 13, the artist is the only one to speak in imagery and in sentence fragments, the only one with whom a synaesthetic physical language is associated. Tian the lute player responds to Kung not with Tseu-Lou's moral earnestness ("I would put the defenses in order") but with a pastoral lyricism grounded by the thoroughly unsentimental word "flopping": "And Tian said . . . . . / 'The old swimming hole, / And the boys flopping off the planks, / 'Or sitting in the underbrush playing mandolins"' (Cantos 58). One change in teaching institutions that Pound proposes early in his career, in "America: Chances and Remedies II," involves just this emphasis on artist-centered 
conversation: "To drive the actual artist upon the university seminary; to restore something like fervour and well-lit discussion, citing as precedent the conditions existing in the University of Paris in the time of Abelard" (34). The artist's only responsibility in this imagined "super-college" is to show up "at a general sort of club rooms reasonably often, to quarrel, to dispute, to fraternize with, to backbite and to accelerate his fellows" ("America V" 116). Although theoretically conversation is a model of democratic give-and-take (it can take place anywhere, and in any classroom), pedagogic conversation in Pound's world takes place among a small number of the elect. The social format is often that of an avant-garde coterie ("Picabia's of a Sunday about 1921 or '22" [Guide 84]). Sites of pedagogic conversation that Pound constructed himself included his Hamilton and Wabash College soirees, "his London Tuesdays in 1910" (McDonald 47), his Rapallo postconcert study groups and, most famously, the Ezuversity in Rapallo, embodied in Pound's own person. ${ }^{14}$

Coterie conversation in a "club room" among one's "fellows" and "Picabia's of a Sunday" on the one hand, "village schools" on the other: these polar pedagogic sites return us to that central paradox of Pound's career, his desire simultaneously to teach and to exclude. The idea of poetry as sacred knowledge continues in the early, career-defining work of a later experimental poet-pedagogue and maker of reading lists heavily influenced by Pound, Charles Olson. ${ }^{15}$ Beyond the question of direct influence, Olson is a crucial figure for the ways in which he furthered and transformed a Poundian tradition of pedagogical avant-gardism: locating that pedagogy within an experimental academic institution; opening his poetry, in a way that Pound never did, to academic tropes; and foregrounding pedagogy as a constitutive feature of postmodern poetics. This set of concerns particularly drives one of Olson's major poems, "The Praises," written in 1950 after he had given up both a conventional academic career and a political career and started teaching at the radically alternative Black Mountain College. (In the same year, Olson writes in the essay "The Gate and the Center" that "the poet is the only pedagogue left, to be trusted" [Collected Prose 170]). While Robert von Hallberg reads "The Praises" usefully as holding to "a strategic enclave theory of culture" (Charles Olson 15), involving a didactic address from a consciously peripheral position, he does not attend to the specific institutional nature of that position or to the poem's foregrounding of teacher-student relations. What is important for my argument, for understanding the development of avant-garde poets' relationship to pedagogy, is that with Olson's work during his Black Mountain years, Pound's coterie audience of initiates has moved into the academy, even if into a marginal area of it, and into a college with a curriculum centered on the arts. From one point of view, this is exactly what Pound wanted, except that the move does not involve a stable institution. (Black Mountain went bankrupt and closed in 1956.)

“The Praises" in one of Olson's sources, Plutarch's Morals, are specifically those of the number five, a key number in Pythagorean thinking, but more generally they are directed in the poem toward the principle of coterie knowledge and audience, the modern Pythagorean brotherhood, that Black Mountain College 
represented for Olson. ${ }^{16}$ The poem's diction is most un-Poundian, expository and even academic, the language of the pedant writing a poem-essay and aiming to teach. Olson establishes this mode early in the hypotaxis and dry diction of the first stanza, with its introduction of a "master" teacher, Pythagoras, and footnotelike claims to scholarly credibility: "(or so Aetius reports, in the Placita)" (Collected Poems 96). He proposes that "we" - both the "we" of scholarly convention and an Olsonian avant-garde - "shall attack" (not "approach" or any number of other possible verbs) by the analytic use of arcane knowledge, the Fibonacci Series, dating back to 1202 (97). The discourse continues to be that of the academic, with summarizing transitions and overt connectives marking stages in a argument: "So we have it"; "Here we must stop And ponder" because we face a contradiction; "we turn now to Ammonius" (97-98). We turn particularly, in part 2 of the poem, to Ammonius's summary of the stages of Pythagorean knowledge, the key feature of which for Olson's purposes is that it "must remain enigmatic" and "excepts . . . / those who are entirely brutish" (99).

All this turns out to have been exposition, the end of which Olson announces in another academic turn: "Which brings us to what concerns us in the present inquiry," the effort (in Poundian imagery) to "avoid / pollution, to be clean / in a dirty time" by self-marginalizing immersion in forms of knowledge open only to initiates, in this case the Pythagorean brotherhood (Collected Poems 99). This stance rests on a stereotypically high modernist sense of decline that is actually uncharacteristic of Olson: "What has been lost / is the secret of secrecy" (100). The problem is "the dispersion which follows from / too many having too little / knowledge" (100). (Olson is writing this poem, remember, in the early years of the G.I. Bill.) Dispersion of the Pythagorean secrets is an "impiety" that, in part 3 of the poem, results in death or exile, depending on one's source, for Hippasus. By contrast, the "containment" that transmits this knowledge for use solely by selected others yields political power and cultural influence (100). From Pythagoras to Philalaos to Archytas to Plato the initiation is passed on (in a homosocial chain not unconnected, one might speculate, to Olson's notoriously demeaning attitude toward female students). Knowledge is literal power when the Pythagoreans are able to "[take] over power, political power, in Gr Greece," suffer its decline, and re-establish a Pythagorean state at Tarentum (101).

"The Praises" concludes in the mixture of the expository and the elliptical that has marked the whole poem. Part 4 begins with a summarizing transition - "which is about what we had to say" - that introduces both a kind of belated thesis ("what belongs to art and reason is the knowledge of consequences") and a withholding of full statement: "the clues, anyhow" (101). "What we have had to say" consists only of clues. In Plutarch's Morals, the riddles of secret knowledge invite inquiry and hence encourage the development of the philosophic mind. In Olson's poem, the reader, along with the Black Mountain student, is left to do his/her own Pythagorean work. ${ }^{17}$

Many of the tropes and the stance of "The Praises" will be familiar to readers of the first volume of The Maximus Poems, which Olson was writing while teaching 
at Black Mountain College and in between drafting course descriptions, syllabi, reading lists, catalogue copy, memos to colleagues, letters to potential benefactors and visiting scholars - all the mundane writing tasks of the working academic that Olson somehow managed to invest with his visionary pedagogical fervor. Apostrophe and the imperative mode run throughout Maximus, which Olson consistently addresses to an intellectual coterie that recalls both "The Praises" and a Poundian pedagogy: "the few of us there are / who read" (Maximus 24). In the widely cited formulation of "Letter 3," "polis now / is a few" (11), but that few constitutes a potentially influential pedagogical minority: "so few / have the polis / in their eye / . . / So few need to, / to make the many share (to have it, / too)" (28-29). As we move through the sequence, "Tyrian Businesses" (which began as a prose piece for a Black Mountain student) begins with the announcement of a lesson plan: "This is the exercise for this morning" (35). "Letter 10" features a typically essayistic beginning, announcing its subjects, posing a topic question and answering it for a thesis: "on John White / on cod, ling, and poor-john, // on founding: was it puritanism, / or was it fish? // . . // It was fishing was first" (45). This self-conscious avant-gardist's early style, then, is marked by academic — or at least discursive - conventions, by the tropes that professors use. From this point of view, the use of footnotes that emerges later in the volume (in "The Record," for instance) is almost predictable, while "Letter 23" ends with a lecture-like summary, as if designed for note-taking, complete with enumerated main points:

What we have in this field in these scraps among these fishermen, and the Plymouth men, is more than the fight of one colony with another, it is the whole engagement against (1) mercantilism (cf. the Westcountry men and Sir Edward Coke against the Crown, in Commons, these same years - against Gorges); and (2) against nascent capitalism except as it stays the individual adventurer and the worker on share....

(Maximus 105)

Appropriately, since Pound's teaching is often conducted through a persona, so too was at least one of Olson's most vigorous responses to that teaching. Olson's "I, Mencius, Pupil of the Master" casts the relationship to the older poet in pedagogical terms beginning with its title. Published in Black Mountain Review (a coterie publication with the broader goal of making the college more visible) in winter 1954, the poem responds in the rather transparent persona of Mencius to what Olson saw as Pound's disastrous translations in Shib-ching: The Classic Anthology Defined by Confucius. For Olson / Mencius, Pound's Confucius translation "clank[s]" like the iron and steel mills of Pittsburgh, and its formal failure constitutes a failure in the "master" Pound's teaching: "To clank like you do / he brings coolie verse / to teach you equity, / who layed down such rails!" (Collected Poems 318) (As Chinese labor, "coolies," laid railroads using Pittsburgh iron and steel, Pound laid poetic rails for later writers to ride on.) Pound has compromised his own teaching on the relationship between civics and aesthetics, and "he / who taught us all / that no line must sleep, / that as the line goes so goes / the Nation" has been "embraced by the demon / he drove off!" (319). "In 
the East the sun untangles itself / from among branches" (319): the pupil is outraged that this memorable image from Fenollosa's The Chinese Written Character, which Pound edited into one of his great teaching texts for young poets, "should be made to sound" like the traffic of men "hustl[ing]" to work at the naval shipyard in Bremerton, Washington (319). The master prosodist is no longer a viable formal teacher, because on the evidence of Pound's Classic Anthology "the great 'ear / can no longer 'hear," the misplaced apostrophes calling up Pound's usually embarrassing bastardized Cockney (319).

Reinforcing further his argument with Pound's prosody, Olson begins part III with an almost verbatim nod to the balladic rhyme scheme and rhythms of A. E. Housman's "We'll to the woods no more," which he has already invoked in alluding to a popular song of the time:

... o Solomon Levi

in your store on Salem Street,

we'll go there to buy our ulsterettes,

and everything else that's neat (Collected Poems 320) ${ }^{18}$

In Olson's layered critique, then, the metres of Pound's Classic Anthology align him with the formal conventionality of Housman, with the marketplace and perhaps the jingles of advertising, with the cheapness of "shoddy" and with commercial art: "open galleries / And sell / Chinese prints, at the opening" $(319,318)$. Pound's Confucius "let[s] decoration thrive" (318), in another oblique reference to Olson's conflicted filial and student status. Shakespeare's King Lear cries "Let copulation thrive; for Gloucester's bastard son / Was kinder to his father than my daughters" (4.6.117-18). By this point in his career, the poet of The Maximus Poems, set in Gloucester, Massachusetts, is very much Gloucester's bastard son as well as Pound's, though he's being none too kind to his father. In turning away from Poundian teaching, Olson simultaneously rewrites and moves back through the master's poem "A Pact" to Whitman, rejecting Pound's "old clothes" in a highly charged Oedipal ellipsis: ". . . let us bite off Father's" (Collected Poems 320). "It is too late / to try to teach us," Olson writes: Pound's Orientalism, marching on clanking metrical "feet," is inadequate to the contemporary American moment, while "our feet / . . do not march" (320) but dance. Pound had closed Canto 13 with the lines "the blossoms of the apricot / blow from the east to the west, / And I have tried to keep them from falling"' (Cantos 60). In Olson's poem, however, even that earlier Pound / Confucius is cut off by another ellipsis - "that the willow or the peach blossom / ..." (Collected Poems 318) — as if, again, he can no longer "teach us." Olson writes in a 1948 note that "a long time ago ... Pound took the role of Confucius, put on that mask, for good. I'm sure he would rest his claim ... forward, as teacher of history to come" (Charles Olson 101). Although he regained his respect for Pound's work, in "I, Mencius," Olson takes on the role of Mencius to dispute Pound's claims "as teacher of history" and, at least temporarily, as a poetic teacher. To invoke Pound's own terms, Olson plays Abelard, disputing with and displacing the professor in Paris. 
Olson was a teacher, and in many of his early poems he writes like one. In an unlikely conjunction, the forms of his institutional life are the forms of his avant-garde poetics. With "The Praises" in particular, we can address the apparent political contradictions of the committed democrat embracing coterie knowledge by reading the poem in terms of an avant-garde pedagogy in two senses: Olson is laying out what form the pedagogy of an avant-garde might take, what kinds of influence it might aspire to, and is in turn teaching his Black Mountain audience how to be, how to behave as, an avant-garde. Thus Olson is defending the principles on which Black Mountain could be seen to rest and projecting his hopes for an improbable cultural influence. But his work also embodies a continuing conflict within avant-garde poetics that is central equally to him and Pound: the conflict between the (public) didactic impulse and the (private) impulse toward preservation of coterie. Among current poets associated with the idea of an avant-garde, namely Language writing, poets who are in many cases continuing to work the relationship between avant-garde poetics and pedagogy, Bob Perelman offers testimony that such a conflict can be as enabling for subsequent readers and poets as it is confounding. Narrating his own initial immersion as a young poet in Pound, Perelman foregrounds Pound's pedagogical texts: "The first conscious traces were left by $A B C$ of Reading and soon after, Guide to Kulchur. I was an aspiring poet and Pound's panache, humor and aggression won me over completely: as Pound revealed it, poetry was a vast, learnable field, always lively, always immediate" ("Pound's Legibility" 34-35). And that, surely, is just how Pound would have wanted it.

\section{Acknowledgements}

A few paragraphs of this essay have appeared previously in my "American Poetry and the PoetTeacher," and the last four sentences in my "Time to Translate Modernism into a Contemporary Idiom." My thanks to the Commonwealth Center for the Humanities and Society at the University of Louisville for supportive funding and to Bob Perelman for comments and conversation.

\section{Notes}

1. While Pound's importance for Olson is widely acknowledged, especially useful discussions of it can be found in von Hallberg, Charles Olson; Beach 84-135; and, in Olson's own words, in Charles Olson and Ezra Pound.

2. For this particular, and useful, definition of the avant-garde, see von Hallberg, "Poetry, Politics, and Intellectuals."

3. On the relationship between avant-garde poetics and pedagogy in the contemporary moment, see Golding, "Isn't the Avant-Garde Always Pedagogical," and, more generally, Retallack and Spahr.

4. McDonald 121-35 usefully situates Pound and Eliot in relation to the debates over education between Irving Babbitt and John Dewey (whose philosophy underlies that of Black Mountain). While McDonald reads Pound with some justification as predominantly Deweyan, the tensions in 
his work that I am exploring in this essay can be also be seen as reflecting the different appeal of both philosophies to Pound.

5. Against Pound's persistent self-characterization as the star "Romanist" of his class, it is worth setting George Dekker's observation that "Pound never got the apprentice stage as a Romance scholar, the stage marked 'promisingly' in The Spirit of Romance" (112). As Dekker adds, however, the 1928 publication of his Cavalcanti essay and translation of "Donna mi priegha" marks his break with the romantic medievalism of his earlier years.

6. Davidson alludes here to Pound's desire for a transhistorical critical method that would "weigh Theocritus and Yeats with one balance" (Spirit 8). Changes in the poetry anthology market during the modern period constitute another context for Pound's pedagogical texts. In his discussion of the anthologies that Pound edited between 1914 and 1933, John G. Nichols argues that "Pound's later anthologies experiment with the more explicit forms of interpretive advice that mainstream anthologies increasingly used by the 1930s, such as prefaces and explanatory footnotes. Pound responded strategically to the dominance of mainstream anthologies, which by the 1930s had marginalized coterie collections and had become the primary means of representing contemporary verse to general audiences" (180). That is, Pound came to insist "one MUST tell the reader" ( $A B C$ 95) due to the audience expectation for explanatory apparatus established by other anthologies.

7. One immediate response to Pound's essay, suggesting its possible (if indirect) impact on English higher education, came in the form of F. R. Leavis's How to Teach Reading (1932).

8. Pound apparently has Louis Untermeyer in mind here. He complains in Guide to Kulchur of how inaccuracy "festers inexcusably in the chronology of Untermeyer's anthologies" (55).

9. The first (1919) edition of Sir Arthur Quiller-Couch's The Oxford Book of English Verse 1250-1900 indeed includes only the first twenty lines of Donne's poem. The 1940 edition, by then entitled The Oxford Book of English Verse 1250-1918, includes the whole poem. I do not know in which of the many intervening editions the change was first made.

10. Pound apparently has the story of Adams, who taught medieval history at Harvard 1870-77, from George Santayana (Letters 348). It is based on chapter 19 of The Education of Henry Adams, "Chaos."

11. Pound's typical rhetorical strategy is to dismiss academics en masse while citing or invoking them selectively, on an individual basis, for support. Thus he claims that "Prof. Rostovtzeff of Yale" would support his view of the Roman economy (Guide 41); praises "Dr Soddy, in Butchart's collection Tomorrow's Money," who has an independence explainable by his being "a prof. of physics, NOT of hired economy" (46-47, 246); and notes how "Prof S. used to sneer at philosophy" and its alleged failure to define terms just as Pound himself does (49). "Dr Breasted of Chicago" is a rare exception to the universities' failures of distribution and communication (61-62).

12. For the origins of this narrative, see Abelard's own "Historia calamitatum" (The Story of His Misfortunes"), in The Letters of Abelard and Heloise 57-106 and especially 58-65.

13. The "time" involved stretches from the 1925 A Draft of XVI Cantos up to and including the 1956 edition of the Cantos, although the nature of the error itself changed during this period: by the 1930 A Draft of XXX Cantos, it involves a repetition not of all three of the lines cited but of the first and third. It was temporarily corrected, apparently by Pound himself, in the 1933 English edition of A Draft of XXX Cantos published by Faber (Gallup 72). Kenner notes that the repetition is silently corrected in the 1971 New Directions edition of The Cantos, adding that, despite Pound's "sanction," on the one hand he "seems never to have requested an emendation of Faber" that would restore the repetition and, on the other hand, allowed it to disappear "from the New Directions in his lifetime without his protest" (xiii-xiv).

14. Through the voice of Yeats in "This Is Yeats Speaking” (1945), Charles Olson describes Rapallo as "the village in the Chinese poem to which the official retire, inhabited by old men devoted to the classics" (Charles Olson 28), oddly anticipating the Confucian ideal of Canto 99: "to have masters in village schools / To teach "em classics not hog-wash" (Cantos 704). We might connect Pound as 
one-man Ezuversity with Jacob Needleman's account of pedagogic transmission and the teacher's role as embodiment of ideas in the Pythagorean cult, cited by Stephen Fredman in his discussion of Olson's "The Praises": "Incarnated in a great teacher, great ideas become pure energy and love - the teacher acts and lives the ideas; they are his being. The teacher is his knowledge" (qtd. in Fredman 61).

15. While the content of Olson's reading lists resembled that of Pound's hardly at all, his conversations with Pound at St. Elizabeth's led him, in a 5 May 1946 letter to James Laughlin, to propose a "low-priced modern classics series," "the New Eliot 5 ft., the New Loeb" (qtd. in Maud 67). While Olson's first reading of Pound consisted of Personae in early 1945, and while we know that he was rereading the early Cantos by February 1945 and owned Eleven New Cantos XXXI-XLI by 29 January 1946, much of his early reading of Pound consisted of the older poet's pedagogic prose. Olson's notebooks show that he read Jefferson and/or Mussolini and Instigations in June 1945, and probably $A B C$ of Economics. Evidence suggests that he had also read Guide to Kulchur, Make It New, and Ta Hio: The Great Learning in the period 1945-46 (Maud 63-67).

16. I use the term "brotherhood" advisedly. The aggressive homosociality of Olson's poetics receives particularly useful analysis in Davidson, Guys Like Us 28-48, and DuPlessis, Blue Studios 73-95.

17. Cf. Pound's remark that "the student knows, or can ferret out the evidence, that ... Pythagoras did teach a modus vivendi" (Guide 25).

18. Olson's version of Housman reads "We'll to these woods / no more" (320), and the reference includes what he sees here as the failed Poundian claim, in "A Pact," to carve the new "wood" broken by Whitman. Olson has alluded to "A Pact" earlier in the poem. He cites the popular song about Solomon Levi (or, at least, one of its multiple versions) almost exactly: "My name is Solomon Levi / And my store's on Salem Street; / That's where to buy your coats and vests / And everything else that's neat" (Alft). Thanks to Tim Redman for pointing out this reference. Before his conversion in 1390, the historical Solomon Levi was rabbi of Burgos, where "my Cid rode up to" in Canto III (Cantos 11).

\section{Works Cited}

Adler, Mortimer J. How to Read a Book: The Art of Getting a Liberal Education. New York: Simon and Schuster, 1940. Print.

Alft, E. C. Chapter 9. Elgin: Days Gone By. ElginHistory.com. Michael Alft. 2001. Web. 9 Feb. 2010.

Baumann, Walter. The Rose in the Steel Dust: An Examination of the Cantos of Ezra Pound. Coral Gables, FL: U of Miami P, 1970. Print.

Beach, Christopher. ABC of Influence: Ezra Pound and the Remaking of American Poetic Tradition. Berkeley: U of California P, 1992. Print.

Coyle, Michael. Ezra Pound, Popular Genres, and the Discourse of Culture. University Park: Pennsylvania State UP, 1995. Print.

Davidson, Michael. Ghostlier Demarcations: Modern Poetry and the Material Word. Berkeley: U of California P, 1997. Print.

- Guys Like Us: Citing Masculinity in Cold War Poetics. Chicago: U of Chicago P, 2004. Print.

Dekker, George. Sailing After Knowledge: The Cantos of Ezra Pound. London: Routledge, 1963. Print.

DuPlessis, Rachel Blau. Blue Studios: Poetry and Its Cultural Work. Tuscaloosa: U of Alabama P, 2006. Print.

Epstein, Andrew. “Verse vs. Verse.” Lingua Franca 10.6 (September 2000): 45-54. Print.

Fenollosa, Ernest. The Chinese Written Character as a Medium for Poetry. Ed. Ezra Pound. 1936. San Francisco: City Lights, 1964. 
Fredman, Stephen. The Grounding of American Poetry: Charles Olson and the Emersonian Tradition. New York: Cambridge UP, 1993. Print.

Froula, Christine. To Write Paradise: Style and Error in Pound's Cantos. New Haven, CT: Yale UP, 1984. Print.

Gallup, Donald C. A Bibliography of Ezra Pound. London: Rupert Hart-Davis, 1969. Print.

Golding, Alan. "American Poetry and the Poet-Teacher." A Concise Companion to Twentieth-Century American Poetry. Ed. Stephen Fredman. Malden, MA: Blackwell, 2005. 55-74. Print.

_. From Outlaw to Classic: Canons in American Poetry. Madison: U of Wisconsin P, 1995. Print.

. "Isn't the Avant-Garde Always Pedagogical': Experimental Poetics and/as Pedagogy." Retallack and Spahr. 13-29.

—. "'Time to Translate Modernism into a Contemporary Idiom': Pedagogy, Poetics, and Bob Perelman's Pound." Shofar: An Interdisciplinary Journal of Jewish Studies 27.3 (2009): 16-29. Print.

Hejinian, Lyn. My Life. Los Angeles: Sun \& Moon, 1987. Print.

Kenner, Hugh. Introduction. Ezra Pound's Cantos: The Story of the Text. By Barbara C. Eastman. Orono, ME: National Poetry Foundation, 1979. xi-xix. Print.

Laughlin, James. "Pound's Pedagogy." Pound as Wuz: Essays and Lectures on Ezra Pound. St. Paul, MN Graywolf, 1987.34-51. Print.

Leavis, F. R. How to Teach Reading: A Primer for Ezra Pound. Cambridge: Minority P, 1932. Print.

The Letters of Abelard and Heloise. Trans. Betty Radice. London: Penguin, 1974. Print.

Lindberg, Kathryne V. Reading Pound Reading: Modernism After Nietzsche. New York: Oxford UP, 1987. Print.

Marshall, Tod. “Ten Cats. Your Score: Verrrrry Good': An Ezra Pound Correspondence Course.” Paideuma 28.1 (1999): 133-48. Print.

Maud, Ralph. Charles Olson's Reading: A Biography. Carbondale \& Edwardsville: Southern Illinois UP, 1996. Print.

McDonald, Gail. Learning To Be Modern: Pound, Eliot, and the American University. New York: Oxford UP, 1993. Print.

Nelson, Cary. Repression and Recovery: Modern American Poetry and the Politics of Cultural Memory, 1910-1945. Madison: U of Wisconsin P, 1989. Print.

Nichols, John G. "Ezra Pound's Poetry Anthologies and the Architecture of Reading." PMLA 121.1 (Jan. 2006): 170-85. Print.

Olson, Charles. Charles Olson E Ezra Pound: An Encounter at St. Elizabeth's. Ed. Catherine Seeleye. New York: Grossman, 1975. Print.

- The Collected Poems of Charles Olson Excluding the Maximus Poems. Ed. George F. Butterick. Berkeley: U of California P, 1987. Print.

C Collected Prose. Ed. Donald Allen and Benjamin Friedlander. Berkeley: U of California P, 1997. Print.

—. The Maximus Poems. Ed. George F. Butterick. Berkeley: U of California P, 1983. Print.

Perelman, Bob. "Pound's Legibility Today: Pedagogy and/or Imitation." Ezra Pound and Referentiality. Ed. Helene Aji. Paris: Presses de l'Universite de Paris-Sorbonne, 2003. 31-41. Print.

. The Trouble with Genius: Reading Pound, Joyce, Stein, and Zukofsky. Berkeley: U of California $\mathrm{P}, 1994$. Print.

Pound, Ezra. ABC of Reading. 1934. New York: New Directions, 1960. Print. 
—_. "America: Chances and Remedies II." The New Age 8 May 1913: 34. Print.

_. "America: Chances and Remedies III." The New Age 15 May 1913: 57-58. Print.

_. "America: Chances and Remedies V." The New Age 29 May 1913: 115-16. Print.

- The Cantos. London: Faber \& Faber, 1987. Print.

- and Marcella Spann, eds. Confucius to Cummings: An Anthology of Poetry. New York: New Directions, 1964. Print.

—. Guide to Kulchur. 1938. New York: New Directions, 1970. Print.

—. The Letters of Ezra Pound 1907-1941. Ed. D. D. Paige. New York: Harcourt, 1950. Print.

—. Literary Essays of Ezra Pound. Ed. T. S. Eliot. 1935. New York: New Directions, 1968. Print.

- Personae: Collected Shorter Poems of Ezra Pound. London: Faber, 1952. Print.

- "Raphaelite Latin." Ezra Pound's Poetry and Prose: Contributions to Periodicals. Vol.1: 1902-1914.

Eds. Lea Baechler, A. Walton Litz and James Longenbach. New York: Garland, 1991. 5-8. Print.

—. Selected Prose 1909-1965. Ed. William Cookson. London: Faber, 1973. Print.

—. Shib-ching: The Classic Anthology Defined by Confucius. Cambridge, MA: Harvard UP, 1954. Print

- The Spirit of Romance. New York: New Directions, 1968. Print.

Retallack, Joan, and Juliana Spahr, eds. Poetry and Pedagogy: The Challenge of the Contemporary. New York: Palgrave/St. Martin's, 2006. Print.

Shakespeare, William. The Complete Works. London: Allen Lane The Penguin P, 1969. Print.

Silliman, Ron. "The Marginalization of Poetry by Bob Perelman." The Impercipient Lecture Series 1:4 (1997): 1-13. Print.

Stein, Gertrude. Selected Writings of Gertrude Stein. Ed. Carl Van Vechten. New York: Vintage, 1990. Print.

von Hallberg, Robert. Charles Olson: The Scholar's Art. Cambridge, MA: Harvard UP, 1978. Print.

_- "Poetry, Politics, and Intellectuals." Cambridge History of American Literature. Vol. 8: Poetry and Criticism 1940-1995. Ed. Sacvan Bercovitch. New York: Cambridge UP, 1996. 9-259. Print.

Whitman, Walt. Leaves of Grass and Other Writings. Ed. Michael Moon. New York: Norton, 2002. Print. 